\title{
Myocarditis in three patients with dengue virus type DEN 3 infection
}

Dengue fever is caused by four dengue virus serotypes, DEN 1, 2, 3, and 4 which are antigenically related, closely [1]. Myocarditis and cardiac dysfunction are recognised complications of dengue fever, but very few studies have identified the causative dengue virus (DEN) type [2]. We report three cases of DEN 3 who had significant cardiac dysfunction suggestive of myocarditis in an outbreak of dengue fever in Kandy, Sri Lanka in April 2005.

Blood samples were obtained within four days of the onset of fever and subjected to RT-PCR-AGE (Agarose gel electrophoresis) assay and Semi-nested-PCR-AGE assay [3]. Acute sera were tested for IgM antibodies using MAC-ELISA and rapid strip test to detect high titres of both IgM and IgG.

\section{Case 1}

A 37-year old male medical doctor was admitted with high fever, headache, myalgia and nausea for 3 days. Pulse rate was $74 / \mathrm{min}$, regular, low volume and blood pressure was 100/70 mmHg. He had no clinical evidence of bleeding. He felt tiredness and intermittent chest discomfort. Investigations are shown in Tables 1 and 2. On the 4th day of fever he collapsed while straining at micturition with bradycardia of 38 beats per min and blood pressure $80 / 50 \mathrm{mmHg}$. He was resuscitated and the ECG showed ST segment changes which reverted in five hours. The fever lasted for 5 days and ECG changes reverted to normal on the 10th day of illness. Repeated 2-dimensional echocardiograms were normal.

\section{Case 2}

A 32-year old woman was admitted with fever, headache, myalgia and nausea of one day's duration. Pulse rate was $126 / \mathrm{min}$ and blood pressure dropped to $84 / 56 \mathrm{mmHg}$ on the second day of fever. There was no evidence bleeding or effusions. The ECG showed sinus tachycardia with an abnormal ST segment (Table 1). She became stable on the 4th day and the ECG reverted to normal on the 6th day of illness.

Table 1. ECG, echocardiography, serology and dengue virus type in the patients

\begin{tabular}{|c|c|c|c|c|c|}
\hline Case & 1st ECG & 2nd $E C G$ & $\begin{array}{c}\text { Lowest Ef* } \\
(\%)\end{array}$ & $\begin{array}{c}\text { ELISA } \\
\text { test }\end{array}$ & $R T-P C R^{* *}$ \\
\hline 1 & $\begin{array}{l}\text { 3rd day. T inversion L1, V1-V6; } \\
\text { Flat T } 11,111 \text {, avF, avL }\end{array}$ & $\begin{array}{l}\text { 4th day. ST elevation L1, avL, V2-V5; } \\
\text { ST depression } 11,111 \text {, avF }\end{array}$ & 53 & $\operatorname{IgM}$ & DEN 3 \\
\hline 2 & $\begin{array}{l}\text { 2nd day. ST depression V4-V6; } \\
\text { T inversion } 11,111 \text {, avF }\end{array}$ & Same as first ECG & 56 & $\operatorname{IgM}$ & DEN 3 \\
\hline 3 & 2nd day. T inversion 111, avF, V1 & 3rd day. $\mathrm{T}$ inversion V2-V5, Flat T 11, V6 & 59 & $\operatorname{IgG}$ & DEN 3 \\
\hline
\end{tabular}

*Ef = ejection fraction measured using echocardiography

**RT-PCR $=$ Reverse transcriptase

Vol. 51, No. 2, June 2006 
Table 2. Haematological and biochemical investigations of the patients

\begin{tabular}{llllccc}
\hline Case & Troponin $T$ & $\begin{array}{l}\text { AST } \\
(\text { Units } / l)\end{array}$ & $\begin{array}{l}\text { ALT } \\
(\text { Units } / l)\end{array}$ & $\begin{array}{l}\text { Lowest WBC } \\
\left(\times 10^{9} / l\right)\end{array}$ & $\begin{array}{l}\text { Lowest platelet } \\
\text { count }\left(\times 10^{9} / l\right)\end{array}$ & $\begin{array}{l}\text { PCV } \\
(\%)\end{array}$ \\
\hline 1 & + & 88 & Normal & 1.9 & 100 & $34-45$ \\
2 & - & Normal & Normal & 1.8 & 96 & $35-39$ \\
3 & + & 342 & 302 & 2.2 & 94 & $36-39$ \\
\hline
\end{tabular}

$\mathrm{AST}=$ aspartate transaminase, $\mathrm{ALT}=$ alanine transaminase $($ normal $<40 \mathrm{U} / \mathrm{l}), \mathrm{PCV}=$ packed cell volume

\section{Case 3}

A 31-year old woman nursing officer was admitted with fever, headache, myalgia, nausea and vomiting for 2 days. Pulse rate was 68/min and the blood pressure was $140 / 80 \mathrm{mmHg}$. Her ECG was abnormal on admission (Table 1) and reverted to normal on the 8th day.

\section{Discussion}

We describe 3 cases of myocarditis caused by DEN 3 virus. The importance of this study is in the identification of the causative virus type as DEN 3 for the first time in the literature. However, we observed 5 cases of myocarditis in a series of 404 dengue cases at Peradeniya, but the causative dengue serotype was not identified [4]. DEN 2 has been identified to a cause myocardial dysfunction of children who had DHF/DSS in a series of 17 patients in India [2]. Their finding had a major impact on the elucidation of the mechanism of shock in fluid resistant DSS. Over the past two decades, DEN 3 had been identified as the cause of epidemics of dengue fever in Sri Lanka, but myocarditis has not been reported [5].

In the cases presented, cardiac involvement was detected in the early phase of the infection. $\mathrm{T}$ wave inversion was the commonest ECG change and relative bradycardia was the problem in 2 cases. Tachycardia was observed in one case. Serology of cases indicates presence of both primary and secondary dengue infection. This unprecedented outbreak of DEN 3 with more cardiac complications could either be due to genetic susceptibility of the host or alteration of the virulence of the viral strain or both. Further virological studies are needed to unravel these problems. For the management of myocarditis we adopted a policy of strict bed rest, oxygenation, and monitoring.

\section{Acknowledgements}

We thank Prof. SN Arsecularatne for the valuable comments.

\section{References}

1. World Health Organisation. Dengue Haemorrhagic Fever: Diagnosis, Treatment, Prevention and Control 1998, Geneva: WHO, Prentice-Hall of India Private Ltd: $1-47$.

2. Wali JP, Biswas A, Chandra S, et al. Cardiac involvement in dengue haemorrhagic fever. International Journal of Cardiology 1998; 64: 31-6.

3. Seah CLK, Chow VTK, Tan HC, Chan YC. Rapid, single step RT-PCR typing of dengue viruses using five NS3 gene primers. Journal of Virology Methods 1995; 51: 193-200.

4. Kularatne SAM, Gawarammana IB, Kumarasiri PRV. Epidemiology, clinical features, laboratory investigations and early diagnosis of dengue fever in adults: a descriptive study in Sri Lanka. Southeast Asian Journal of Tropical Medicine and Public Health 2005; 36: 282-8.

5. Messer WB, Gubler DJ, Harris E, Sivananthan K, De Siva AM. Emergence and global spread of a dengue serotype 3, subtype III virus. Emerging Infectious Diseases 2003; 9: 800-9.

SAM Kularatne, Senior Lecturer in Medicine, Department of Medicine, Faculty of Medicine, University of Peradeniya, Manoji MK Pathirage, Medical Officer, General Hospital, Peradeniya, and UAB Medagama, Senior Registrar in Medicine, General Hospital, Peradeniya, Sri Lanka, and Sunethra Gunasena, Medical Virologist, Medical Research Institute, Colombo 8, and Maya B Gunasekara, Head, Genetech Research Institute, Colombo 8.

Correspondence: SAMK, e-mail: <samkul@sltnet.lk> (Competing interests: none declared). Received 21 October 2005 and revised version accepted 20 January 2006. 